\title{
A DISCUSSION PAPER ON ACCOUNTS PAYABLE RATIO
}

\author{
Cenap Ilter*
}

\begin{abstract}
Generally speaking, financial accounting textbooks are in harmony on the explanation of accounts payable and accrued liabilities/expenses. However, the same thing cannot be said for accounts payable turnover and days in accounts payable ratios. Different financial accounting textbooks and academic papers have different explanations for the accounts payable turnover ratio. The extant literature on the ratio is mainly comprised of two groups of authors. The first group relates the ratio to purchases and the second group relates the ratio to cost of goods sold (COGS). Purchases, in a purely theoretical sense, relate to periodic inventory method, whereas the perpetual inventory method relates purchases with inventory (being debit) and accounts payable (being credit). The second major group who explain the ratio by using the COGS figure ignore what is included in COGS. It should not include depreciation, amortisation, payroll and interest expenses to be meaningful for the purposes of the calculation of the ratio. In practice, manufacturing companies do not attempt to calculate these ratios due to the difficulty of obtaining the figures. These ratios can only be truly calculated from within the company if need be. Their accounting departments will be able to calculate the ratio correctly since they can reach the data. Any financial analyst not being able to reach a detailed breakdown of the expenses of the companies whose shares are being traded in stock exchanges will not able to calculate these ratios.
\end{abstract}

Keywords: cost of goods sold, purchases, expenses, accounts payable, accrued liabilities JEL Classification: M41

\section{Introduction}

The purpose of this paper is to clarify the inconsistencies of explanations and examples on accounts payable ratios in accounting textbooks. Over the years of teaching and reading different accounting textbooks, the author realised that there were inconsistencies in the explanations and calculation of accounts payable ratios. In relation to the calculation of accounts payable ratio and days to pay accounts payable, it is necessary to explain accounts payable, accrued liabilities/expenses and expenses.

In the course of running their day to day businesses, most companies purchase goods and services from their suppliers. These purchases are normally on credit with cash payments made after the goods and services are delivered. As a consequence, these transactions create liabilities - obligations for the purchaser to make payments in the near future. These liabilities are called accounts payable or trade accounts payable.

\section{Accrued Liabilities}

Accrued liabilities are the obligations that reflect expenses/purchases incurred but have not yet been paid or recorded in accounts payable during an accounting period. In other words, a company's obligation to pay for goods and services that have been provided for which invoices have not yet been received.

* California State University Dominguez Hills, College of Business Administration and Public Policy (Cilter@csudh.edu). 


\section{Expenses}

Expenses are the consumed assets, or any expenditure made to provide and sell goods and services. Expenses, as categorised by nature, include depreciation, amortisation, salaries and wages, gas, water, electricity, travel, communication, cost of goods sold (COGS), insurance, transportation, supplies, parts, rent, interest, custom duties, tax, etc. COGS requires close attention and should be explained for merchandising and manufacturing companies separately. For merchandising companies, it is the cost of the merchandise purchased plus custom duties (if goods are imported), transportation costs and insurance. In other words, all the costs incurred until the goods are ready for sale. In manufacturing industries, COGS include direct material, direct labour, manufacturing overhead in which there are depreciation, indirect labour and all other indirect functional costs such as heating, cooling, maintenance, supervision, janitorial services - anything that is indirectly related with production in a production plant. If the production is made to order type (qualifying asset per International Accounting Standards-IAS 23) then it may include the borrowing costs-interest related to the production of the goods.

\section{Literature Review and Discussion}

Generally speaking, financial accounting textbooks are in harmony on the explanation of accounts payable and accrued liabilities/expenses. However, the same thing cannot be said for accounts payable turnover and days in accounts payable ratios. Different financial accounting textbooks and academic papers have different explanations for the accounts payable turnover ratio. The rest of the section will deal with the excerpts from different accounting textbooks, articles on the subject matter and discuss their inconsistencies.

The extant literature on the ratio mainly has two groups of authors. The first group relates the ratio to purchases and the second group relates the ratio to COGS. There are two exceptions in which a third author relates the ratio to sales and there is another author who includes both purchases and COGS in the analysis.

\subsection{Discussion Part 1: Accounts Payable Ratio Calculations Related with Purchases}

The excerpts below discuss the first part, with those ratios related to purchases:

- The number of days accounts payable (AP) indicates the average time taken by a firm to pay their creditors. The higher the value, the longer the firm takes to settle the payment commitments to creditors, and this is calculated as $365 \times$ [account payable/purchase] (Sharma and Kumar, 2010).

- Calculating accounts payable turnover (purchases divided by accounts payable) and average days' purchases in accounts payable $(365 \div$ accounts payable turnover) gives an indication if the firm is paying its obligations in a timely manner and also taking advantage of discounts (Lewis, 2012).

- Accounts Payable Turnover Ratio is a short-term liquidity measure used to quantify the rate at which a company pays off its suppliers. The accounts payable turnover ratio is calculated by taking the total purchases made from 
suppliers and dividing it by the average accounts payable amount during the same period.

- $\quad$ Average Accounts Payables $=($ Supplier Purchases/ Year $) /(365$ Days/ Year $)$

- Accounts Payable Turnover in days = Accounts Payable/Average Accounts Payables (Rodgers, 2016)

- Average Settlement Period or Accounts Payable Turnover: The average settlement period measures the time it takes to pay creditors. The accounts payable turnover is the number of times trade payables turn over in one year.

- Average settlement period = accounts payable/average purchases per day

- Accounts payable turnover $=$ cost of goods sold/accounts payable (Glantz, 2014)

Divide the total annualised purchases by 365 days, and then divide the result into the ending accounts payable balance. An alternative approach is to use the average accounts payable for the reporting period because the ending figure may be disproportionately high or low. The number of purchases should be derived from all non-payroll expenses incurred during the year (payroll is not included because it is not part of the accounts payable listed in the numerator). Depreciation and amortisation should also be excluded from the purchases figure since they do not involve cash payments. The formula is: Accounts payable/(Purchases/365) (Bragg, 2012).

Purchases, in a purely theoretical sense, relate to the periodic inventory method, whereas the perpetual inventory method relates purchases with inventory (being debit) and accounts payable (being credit). Therefore, relating accounts payable turnover ratio to "purchases" only is theoretically incorrect because it is ignoring the purchases of the perpetual inventory method. Besides, in practice, many companies directly use the inventory account despite the fact that their inventory method is periodic. In a quote from Bragg, it is further explained that purchases should be drawn from expenses excluding depreciation, amortisation and payroll. Here, the term purchases is misused; the term all expenses except depreciation, amortisation and payroll would be more explanatory.

\subsection{Discussion Part 2: Accounts Payable Ratio Calculations Related with COGS}

The excerpts below discuss the second part, with those ratios related to COGS: Days in accounts payable $(\mathrm{A} / \mathrm{P})$ measures how long it takes for the practice to pay its bills. This calculation is made by the ending accounts payable divided by the cost of sales divided by the number of days (Norris, 2015).

We calculated various working capital ratios in Chapter 1 although there is no standard accounts payable ratio. RMA (the Risk Management goods Association) publishes supplemental ratios including payables turnover, defined as the cost of goods sold (cost of sales) divided by payables. For plastics manufacturing, the result is 21,11 , and 8 turns, and 17, 32, and 47 days. The Rengas Company has $\$ 100$ million in cost of goods sold and $\$ 15$ million in payables, resulting in 6.7 turns and 54 days (Sagner, 2010). 
- Accounts Payable Turnover Ratio $=$ Cost of Goods Sold/Average Accounts Payable

- Average Days to Pay Payables = Days in the year (365)/Accounts Payable Turnover Ratio (Libby, Libby and Hodge, 2017)

In this example, the authors combine the ratio with inventory turnover, days to sell inventory and days in accounts receivable to calculate the cash need of the company between the period of payment to suppliers and collection from customers.

The second major group who explain the ratio by using the COGS figure ignore what is included in COGS. As explained above, COGS in merchandising companies are calculated differently than COGS in production companies. If the ratio is going to be applied to manufacturing companies then the analyst needs a breakdown of the calculation of COGS. In this case, COGS should not include depreciation, amortisation, payroll and interest expenses. Interest expense should also be excluded because interest expense is in the other expenses category after the income from operations line on the income statement. Interest has no relation to the operations of the company. Interest expense is included in another set of ratios where the purpose is to calculate the power of the company to pay interest, i.e. the interest coverage ratio is calculated to determine how easily a company pays its interest expenses on outstanding debt. The ratio is calculated by dividing a company`s earnings before interest and taxes (EBIT) by the company's interest expenses for the same period.

\subsection{Discussion Part 3: Accounts Payable Ratio Calculations Related with Sales}

Accounts payable in days: Accounts payable/sales*365. This is another index linked to sales activity. Also known as supplier credit, this ratio measures the extent to which the company avails itself of credit from its suppliers. While modest levels are to be expected, undue variations can be indicative of liquidity problems in the company (Fight, 2006).

Fight's explanation of the ratio might be useful for indicating a trend if followed on consecutive periods otherwise relating sales with accounts payable has no meaningful consequences for calculations of accounts payable turnover and accounts payable in days ratios.

\subsection{Discussion Part 4: Another Common Pitfall in All the Calculations Above}

There is a common pitfall in the whole discussion of calculations of the ratios by different authors. All of the authors above ignore using the accrued liabilities/ expenses figure in their calculations. They just take into account the accounts payable figure as if all expenses, purchases have already been invoiced to the company in question. This assumption has no practical value. In fact, in almost every reporting period there may be some suppliers' invoices not received yet. Therefore, accounts payable turnover and days in accounts payable ratio calculations should also include accrued liabilities or an accrued expenses figure in the liabilities section of the balance 
sheet. Additionally, these two figures should be calculated as average figures [i.e. (beginning of the period + end of the period)/2]. Another point to remember related to ratio calculations is that the calculations above assume all purchases and expenses are made on credit, although some purchases and expenses are made in cash. However, this could only occupy a small portion of the total purchases and expenses in a year and can be ignored in calculations.

\subsection{Discussion Part 5: Author's Examples of Ratio Calculations}

In this section, three different hypothetical companies' expenses are analysed and their respective accounts payable turnover and days in accounts payable ratios are calculated.

Table 1 below explains the ratios in a manufacturing company. Manufacturing companies have high COGS figures as it includes direct labour, indirect labour, direct material, indirect material, utilities and other indirect costs related to production. The hypothetical company has the breakdown of all its expenses. In the calculation of the accounts payable turnover ratio, the denominator (total expenses**) of the ratio excludes labour, salaries, depreciation and amortisation. The reason is that salaries and labour accruals are for the company's own employees and according to company policy are paid at regular intervals (i.e. weekly, biweekly or monthly). Generally speaking, white-collar workers receive monthly pay and blue-collar workers receive either monthly or more frequent pay. Depreciation and amortisation are also allocated on the cost of goods produced and written off as direct expense on the basis of where the tangible and intangible long-term assets are utilised. That is, those related to production are allocated on the inventory of goods produced and reflected on COGS as the goods are sold and others are directly written off as period expense on the income statement. Both depreciation and amortisation have no accumulated depreciation and accumulated amortisation accounts on the liabilities section of the balance sheet and also both accounts reflect the cost allocation of the company's own assets. The formulas of accounts payable turnover ratio and days in accounts payable are as follows:

- Accounts payable turnover $=$ Total expenses**/(average accounts payable + average accrued liabilities)

- Both averages of the formula are calculated as the average of current yearend and previous yearend figures [(current year-end + previous year-end)/2].

- $\quad$ Days in accounts payable $=$ (Average accounts payable + average accrued liabilities)/average daily expenses

- $\quad$ Average daily expenses $=$ Total expenses**/365 
Table 1 | XYZ manufacturing company breakdown of expenses for the year ending Dec. 31, 2019

\begin{tabular}{|c|c|c|}
\hline Expenses & Current Year & Previous Year \\
\hline COGS-Direct material & 200,000 & \\
\hline COGS-Direct labor & 250,000 & \\
\hline COGS-Indirect material & 50,000 & \\
\hline COGS-Indirect labor & 25,000 & \\
\hline COGS-Indirect utility expenses & 25,000 & \\
\hline COGS-Other indirect expenses & 10,000 & \\
\hline Salaries & 400,000 & \\
\hline Telephone and communication & 20,000 & \\
\hline Travel & 40,000 & \\
\hline Rent & 30,000 & \\
\hline Tax & 10,000 & \\
\hline Gas & 5,000 & \\
\hline Electricity & 6,000 & \\
\hline Water & 3,000 & \\
\hline Supplies & 2,000 & \\
\hline Depreciation & 35,000 & \\
\hline Amortization & 3,000 & \\
\hline Insurance & 7,000 & \\
\hline Transportation & 8,000 & \\
\hline Custom duties & 4,000 & \\
\hline Parts & 5,000 & \\
\hline Total expenses & $1,138,000$ & \\
\hline Accounts payable & 55,000 & 50,000 \\
\hline Accrued liabilities* & 5,000 & 6,000 \\
\hline \multicolumn{3}{|l|}{ *Excludes wages and salaries accruals. } \\
\hline Total expenses** & 425,000 & \\
\hline Average daily expenses & 1,164 & \\
\hline Average accounts payable & 52,500 & \\
\hline Average accrued liabilities & 5,500 & \\
\hline Average total accounts payable and average accrued liabilities & 58,000 & \\
\hline Accounts payable turnover ratio & 7 & \\
\hline Accounts payable in days & 50 & \\
\hline **Excludes labor, salaries, depreciation and amortization & & \\
\hline
\end{tabular}

Source: Author`s own example 
According to the figures presented in Table 1, the hypothetical manufacturing company's all third party suppliers send their goods and supply their services to the company and get paid on average seven times a year, which translates that they get paid on average once in every 50 days.

Table 2 below explains the ratios in a merchandising company. Merchandising companies have lower COGS figures as it only includes the cost of the merchandise purchased, its transportation, insurance, and customs duties (if any). The hypothetical company has the breakdown of all its expenses. It also has a lower cost of depreciation and amortisation as it is only buying and selling merchandise not producing it. The same explanations made for the manufacturing company ratios are valid for the merchandising company.

Table 2 | XYZ merchandising company breakdown of expenses for the year ending Dec. 31, 2019

\begin{tabular}{|c|c|c|}
\hline Expenses & Current Year & Previous Year \\
\hline COGS-Goods & 200,000 & \\
\hline COGS-Transportation in & 8,000 & \\
\hline COGS-Custom duties & 4,000 & \\
\hline COGS-Insurance & 7,000 & \\
\hline Salaries & 400,000 & \\
\hline Telephone and communication & 20,000 & \\
\hline Travel & 40,000 & \\
\hline Rent & 30,000 & \\
\hline Tax & 10,000 & \\
\hline Gas & 5,000 & \\
\hline Electricity & 6,000 & \\
\hline Water & 3,000 & \\
\hline Supplies & 2,000 & \\
\hline Depreciation & 20,000 & \\
\hline Amortization & 1,000 & \\
\hline Parts & 2,000 & \\
\hline Total expenses & 758,000 & \\
\hline Accounts payable & 40,000 & 35,000 \\
\hline Accrued liabilities* & 4,000 & 3,000 \\
\hline \multicolumn{3}{|l|}{ *Excludes wages and salaries accruals. } \\
\hline Total expenses ${ }^{* *}$ & 337,000 & \\
\hline Average daily expenses & 923 & \\
\hline Average accounts payable & 37,500 & \\
\hline Average accrued liabilities & 3,500 & \\
\hline $\begin{array}{l}\text { Average total accounts payable and average accrued } \\
\text { liabilities }\end{array}$ & 41,000 & \\
\hline Accounts payable turnover ratio & 8 & \\
\hline Accounts payable in days & 44 & \\
\hline **Excludes salaries, depreciation and amortization & & \\
\hline
\end{tabular}

Source: Author's own example 
The hypothetical merchandising company's expense figures show that its third party suppliers send their goods and supply their services to the company and get paid on average eight times a year, which translates that they get paid on average once in every 44 days.

Table 3 below explains the ratios in a servicing company. Servicing companies have a Cost of Services Sold (or provided) figure and depending on the nature of service, it generally includes labour (the main cost item) and material related to the production of services. The hypothetical company has the breakdown of all its expenses. Similar to the merchandising company, it has a lower cost of depreciation and amortisation as it does not heavily invest in tangible and intangible long-term assets. The explanations made for the ratios of manufacturing company ratios are valid for the servicing company.

Table 3 | XYZ servicing company breakdown of expenses for the year ending Dec. 31, 2019

\begin{tabular}{|c|c|c|}
\hline Expenses & Current Year & Previous Year \\
\hline Cost Of Services Sold-material & 25,000 & \\
\hline Cost Of Services Sold-labor & 250,000 & \\
\hline Salaries & 100,000 & \\
\hline Telephone and communication & 20,000 & \\
\hline Travel & 40,000 & \\
\hline Rent & 30,000 & \\
\hline Tax & 10,000 & \\
\hline Gas & 5,000 & \\
\hline Electricity & 6,000 & \\
\hline Water & 3,000 & \\
\hline Supplies & 2,000 & \\
\hline Depreciation & 20,000 & \\
\hline Amortization & 1,000 & \\
\hline Insurance & 7,000 & \\
\hline Transportation & 8,000 & \\
\hline Custom duties & 4,000 & \\
\hline Total expenses & 531,000 & \\
\hline Accounts payable & 30,000 & 25,000 \\
\hline Accrued liabilities* & 2,500 & 1,500 \\
\hline \multicolumn{3}{|l|}{ *Excludes wages and salaries accruals. } \\
\hline Total expenses** & 260,000 & \\
\hline Average daily expenses & 712 & \\
\hline Average accounts payable & 27,500 & \\
\hline Average accrued liabilities & 2,000 & \\
\hline Average total accounts payable and average accrued liabilities & 29,500 & \\
\hline Accounts payable turnover ratio & 9 & \\
\hline Accounts payable in days & 41 & \\
\hline **Excludes labor, salaries, depreciation and amortization & & \\
\hline
\end{tabular}

Source: Author's own example 
The hypothetical service company's expense figures show that its third-party suppliers send their goods and supply their services to the company and get paid on average nine times a year, which translates that they get paid on average once in every 41 days.

\section{Conclusion}

The ratios in question can only be truly calculated based on the explanations made in part 5 in the discussion. The former ratio analysis in the literature review under discussions 1 through 4 are not based on sound theory. They should be based on expenses rather than purchases. Besides COGS calculations including depreciation, direct labour and indirect labour do not reflect a true calculation of the ratios. In practice, manufacturing companies do not attempt to calculate these ratios due to the difficulty of obtaining the figures, i.e. in order to obtain the depreciation and direct and indirect labour included in COGS, the companies would have to do additional work to clean up the COGS figure from depreciation and labour cost. Considering the current liabilities in general, these are generally due on a monthly basis, i.e. salaries and wages are due once a month (wages might be due more frequently); taxes (sales taxes, income taxes, social insurance obligations, retirement benefits) are normally due once in a month. Accounts payable and accrued liabilities (i.e. rent electricity, gas, water, telecommunication expenses, not invoiced at the end of the reporting period) are normally due once a month. Companies may take advantage of suppliers' discounts for purchases for early payment provided that the discount rate applied is higher than their borrowing rate. Some suppliers may be paid in more than 30 days after the invoice date, but this is an exception rather than a rule because, in general, every business calculates the time value of money and tries to close the gap between collection from customers and payment to the suppliers.

In general, accepting the 30 days payment rule for current liabilities will not mislead companies in balancing their current asset and liability management. For example, if you are paying your current liabilities in 30 days and your days in inventory ratio is 60 and the days in accounts receivable for collection from customers is 30 , this means you have to finance the 60 days gap between current assets and current liabilities (assuming that accounts receivable and inventory are the major items in your current assets, which they usually are). Depending on the nature of the business, this might reflect itself as the company will need short term borrowing to close the gap in collection and payments. As long as the company has current assets exceeding current liabilities and the company is cash-rich and able to earn other income (interest and dividend) from short term investments then the financial burden of the collection and payment gap will be alleviated and will not harm the income statement due to short term borrowing.

Another concluding point is that these ratios can only be truly calculated from within the company if need be. Their accounting departments will be able to calculate the ratio correctly since they can reach the data. Any financial analyst not being able to reach a detailed breakdown of the expenses of the companies whose shares are being traded in stock exchanges will not able to calculate these ratios. Companies who report regularly to stock exchanges do not give the breakdown of their expenses in such detail as given in discussion parts 1 through 4 of this paper. 


\section{References}

Bragg, S.M. (2012). Business Ratios and Formulas: A Comprehensive Guide (3rd ed.). Hoboken, NJ: John Wiley \& Sons.

Fight, A. (2006). Cash Flow Forecasting. Burlington, MA: Butterworth-Heinemann.

Glantz, M. (2014). Navigating the Business Loan: Guides for Lenders, Small Business Owners, and Entrepreneurs. London, UK: Academic Press.

Lewis, L. D. (2012). The Power of Accounting: What the Numbers Mean and How to Use Them. New York, NY: Routledge.

Libby, R., Libby, P., and Hodge, F. (2017). Financial Accounting (10th ed.). New York, NY: McGraw-Hill Education.

Norris, D. J. (2015). 5 Financial Metrics: Every Practice Should Track Each Month. Medical Economics, 92(17), p. 34.

Rodgers, W. (2016). Knowledge Creation : Going Beyond Published Financial Information. Hauppauge, NY: Nova Science Publishers.

Sagner, J. (2010). Essentials of Working Capital Management. Hoboken, NJ: John Wiley \& Sons.

Sharma, A.K., and Kumar, S. (2010). Effect of Working Capital Management on Firm Profitability: Empirical Evidence from India. Global Business Review, 12(1), pp. 159-173. https://doi.org/10.1177/097215091001200110

\section{Online source:}

https://www.iasplus.com/en/standards/ias/ias23 